\title{
Geochemical Characterization of Boula Ibi Granitoids and Implications in Geodynamic Evolution
}

\author{
Jean Paul Sep Nlomngan ${ }^{1,2}$, Joseph Penaye ${ }^{1}$, Rigobert Tchameni ${ }^{3}$, Sebastien Owona ${ }^{4}$, Augustin Patrice \\ Moussango Ibohn ${ }^{1}$, Emmanuel N. Nsifa ${ }^{2} \&$ Toteu Sadrack Félix ${ }^{5}$ \\ ${ }^{1}$ Institut de Recherches Géologiques et Minières, Centre de Recherches Géologiques et Minières de Garoua, \\ Garoua, Cameroun \\ ${ }^{2}$ Département des Sciences de la Terre, Faculté des Sciences, Université de Yaoundé I, Yaoundé, Cameroun \\ ${ }^{3}$ Département des Sciences de la Terre, Faculté des Sciences, Université de N'gaoundéré, N'gaoundéré, \\ Cameroun \\ ${ }^{4}$ Département des Sciences de la Terre, Faculté des Sciences, Université de Douala, Douala, Cameroun \\ ${ }^{5}$ UNESCO, Regional Office for Eastern Africa, Nairobi, Kenya \\ Correspondence: Jean Paul Sep Nlomngan, Centre de Recherches Géologiques et Minières de Garoua, B.P 333 \\ Garoua, Cameroun. Tel: 237-694-641-816. E-mail: jpsep_cm@yahoo.fr
}

Received: October 29, 2019

doi:10.5539/jgg.v11n4p13
Accepted: November 25, 2019 Online Published: November 30, 2019

URL: http://dx.doi.org/10.5539/jgg.v11n4p13

\begin{abstract}
Petrographical and geochemical study, consistent with observed field relations show that the Boula Ibi syn- and post-kinematic granitoids in north Cameroon, occurred in banded gneisses. These syn- and post-kinematic granitoids consist of deformed monzonites typified by its granoblastic texture, diorites, syenites, granites and basic xenoliths of dioritic and monzonitic composition. They are calc-alkaline, hyperpotassic, metaluminous to slightly peraluminous and I-Type granitoids. They display high content in $\mathrm{Fe}_{2} \mathrm{O}_{3}+\mathrm{MgO}+\mathrm{CaO}(2.16-23.24 \%)$ that reveals their intermediate affinity, magnesian and metaluminous character whilst the low A/CNK $(<1.1)$ content indicates their mantle origin. Harker diagrams and $\mathrm{La} / \mathrm{Sm}$ vs La define the fractional crystallization and partial melting as the two main processes that led the geodynamic evolution of the Boula Ibi syn- and post-kinematic granitoids. These are consistent with low-content of $\mathrm{Cs}, \mathrm{Ta}, \mathrm{Nb}, \mathrm{Tb}$ and $\mathrm{Hf}$, supporting high melting rates ranging between 20 and $40 \%$ as well as molar $\mathrm{Al}_{2} \mathrm{O}_{3} /(\mathrm{MgO}+\mathrm{FeOt})$ vs $\mathrm{CaO} /(\mathrm{MgO}+\mathrm{FeOt})$ plot showing magmatic evolutions from metabasaltic and metagreywackes sources.
\end{abstract}

Keywords: Boula Ibi, Cameroon, Garoua, Fractional Crystallisation, Granitoids, Partial Melting

\section{Introduction}

The Pan African Central Fold Belt (PACFB) located between the West African craton, Congo/Sao-Francisco craton and Saharan metacraton, is a large domain that has been remobilized during the Pan African orogeny following the collision of above cratons between 700 and $500 \mathrm{Ma}$ (Castaing et al., 1994; Abdelsalam et al., 2002). In Cameroon, this fold belt is divided into three major domains: the Yaoundé Domain in the South, the Adamawa Yade Domain in the Center, and the North Domain (Toteu et al., 2004; Van Schmus et al., 2008). Several granitoids within the three domains have been classified as pre-, syn- to post- kinematic (Kwekam, 1993; Nguiessi Tchankam et al., 1994; Toteu et al., 2001; Tagne Kamga, 2003; Nzolang et al., 2003; Njanko et al., 2006; Djouka-Fonkwe et al., 2008; Njiekak et al., 2008; Kouankap et al., 2010; Kankeu et al., 2012). These granitoids cover a broad spectrum of composition that ranges from diorites to leucogranites and display great diversity in their origin, sources and evolution processes, and thus can be used as indicators of geodynamic environments and, in some cases as tracers of geodynamic evolution (Hutton et al., 1990; Barbarin, 1999).

The Boula Ibi Region (BIR) is located in the western side of the metavolcano sedimentary Bibemi-Zalbi basin (Figure 1b) within the North Domain that includes medium to high grade schists and gneisses of Neoproterozoic age; pre, syn to late Pan-African granitoid units and post tectonic granitoids (Toteu et al., 2004; Dawaï et al., 2013; Dawaï, 2014; Tchameni et al., 2015). However, the Boula Ibi area that includes several granitoids and seems to be a suitable area for petrology and geodynamic evolution of granitoids is still poorly known. 
The objective of this study is to characterize and constraint the petrogenesis and evolution of the granitoids in the Boula Ibi area using major, trace and REE composition obtained by ICP-MS.

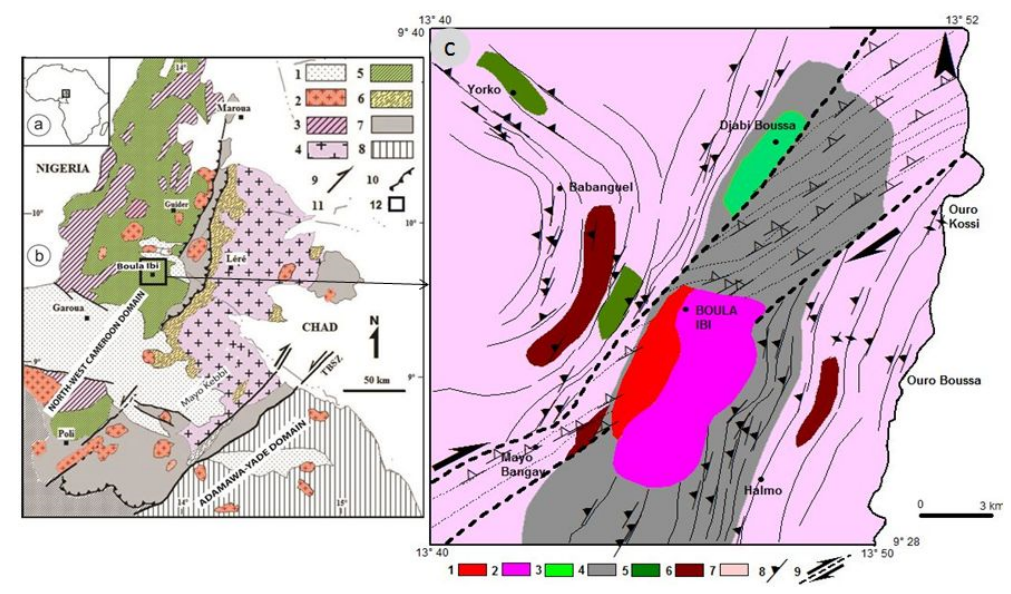

Figure 1. Location of the study area

(a) Location of the study area within the PanAfrican mobile zone of Central Africa; (b) Geological sketch map of the Northern Cameroon domain (modified after Tchameni et al., 2015). (1) Late Pan-African to Recent sediments; (2) late to post-tectonic granitoids; (3) syn-tectonic granitoids; (4) Mayo Kebbi batholith (Tonalite, Trondhjemite and granodiorite); (5) Medium to high grade gneisses; (6) Mayo Kebbi mafic to intermediate complex (metadiorites, gabbro-diorite and amphibolite); (7) Neoproterozoic low to medium-grade metavolcano-sedimentary; (8) Paleoproterozoic Adamaoua Yadé remobilized domain; (9) Faults, Shear Zone; (10) Thrust front; (11) limit of countries; (12) the study area; (c) Geological map of the Boula Ibi area. (1) Granite (2) Syenite (3) Monzodiorite (4) Deformed monzonites (5) Dioritic gneisses (6) Amphibolites (7) Banded gneisses (8) Foliation (9) Shear

\section{Geological Setting}

The NCD domain in which the BIR is bordered in (1) the south and south west by the Tchollire-Banyo fault (Louis, 1970; Pinna et al., 1994; Pouclet et al., 2006; Ngako et al., 2011; Bouyo et al., 2015), to (2) the East by the south-western Tchad domain (Penaye et al., 2006; Isseini et al., 2012; Bouyo et al., 2015) and (3) to the west by the east Nigerian domain (Ferré et al., 1998; 2002; 2006; Ekweme et al., 1997).

The NCD is the northern part of the Pan-African Oubanguide complex of North Equatorial Fold Belt (Toteu et al., 2004; Van Schmuss et al., 2008). It consists of low- to high-grade metapelites, metabasalts, pre-, syn- and post-tectonic granitoids and post-Pan-African volcano-sedimentary cover (Béa, 1986; Ngako, 1986; Bassahak, 1988; Njel, 1988; Toteu et al., 1987; Toteu et al., 2004). Low- to high-grade metapelites belong to the Poli greenstone belt, the Rey Bouba and Bibemi-Zalbi formations. They derive from mafic to intermediate and felsic volcano-sedimentary materials (Pinna et al., 1994; Toteu et al., 1990; 2004; Bouyo et al., 2015), with tholeiitic basalt affinity and calc-alkaline rhyolite protholiths emplaced in extensional crustal environment (Ngako, 1986; Njel, 1988; Toteu et al., 1990). Metabasalts and epiclastites from the Bibémi-Zalbi formations derived from transitional to calc-alkaline andesite and andesitic basalts (Doumnang, 2006; Isseini, 2011; Bouyo et al., 2015). Pre, syn to late tectonic granitoids can be differentiated into calc-alkaline diorite, granodiorite and granite, dissected felsic or mafic dykes (Toteu et al., 2004). Post Pan-African sedimentary and volcanic rocks define sedimentary basins including such as molassic Pan-African deposits as the Mangbei basin which has experienced no or little metamorphism (Bea et al., 1990).

The NCD is affected by two phases of deformation $\mathrm{D}_{1}$ and $\mathrm{D}_{2}$ (Ngako et al., 1990; Nzenti et al., 1992; Toteu et al., 2004). $D_{1}$ phase strongly overprinted by $D_{2}$, is locally preserved by relics of $S_{1}$ flat lying foliation in schists and gneisses. Variation in dip angles is associated to isoclinal fold, rotational structures with a $\mathrm{N} 110^{\circ} \mathrm{E}$ sub horizontal stretched lineation locally preserved (Nzenti et al., 1992; Toteu et al., 2004), outlining the Poli Group tangential $D_{1}$ phase (Nzenti et al., 1992). $D_{2}$ phase is marked by vertical and tight $F_{2}$ folds and $S_{2}$ axial plane schistosity. Mineral lineation and fold axis are parallel and vary from NNE-SSW to NE - SW with weak to intermediate dips ranging between 0 to $50^{\circ} \mathrm{N}$ and $\mathrm{S}$ (Nzenti et al., 1992; Toteu et al., 2004). In the Poli Group, 
$\mathrm{D}_{2}$ phase is associated to regional high-grade metamorphism that emplaced migmatites, anatexite granite, sinistral and dextral faults (Nzenti et al., 1992; Ngako et al., 2008; 2011).

$\mathrm{Rb} / \mathrm{Sr}$ isotopes data and $\mathrm{U}-\mathrm{Pb}$ geochronology on zircon of granitoids from the Northern domain in Cameroon support a juvenile domain of Neoproterozoic age with contamination from an older Ebournean crust without any Archean inheritance. The Rey Bouba and Bibemi-Zalbi volcanites occur at ca. $830 \mathrm{Ma}$ and $665 \mathrm{Ma}(\mathrm{U}-\mathrm{Pb}$ on zr) in the Poli Group (Toteu et al., 1990), and ca. 645-630 Ma (U-Pb on zr) for the greenstone belt in Rey Bouba (Bouyo et al., 2015). Epiclastics and metabasalts from the Bibemi-Zalbi yielded $777 \pm 5 \mathrm{Ma}$ and $700 \pm 10 \mathrm{Ma}$ the (Doumnang, 2006; Isseini, 2011). Pre-, syn- to late tectonic grainitoids emplaced between ca. 660 and 580 $\mathrm{Ma}(\mathrm{U}-\mathrm{Pb} / \mathrm{Zr}$; Toteu et al., 1987; 2001).

\section{Materials and Methods}

\subsection{Materials}

The Boula Ibi region consists of assemblage of various composition gneisses and amphibolites crosscut by magmatic rocks. The intrusives rocks include deformed monzonites in which are intruded undeformed dorites, syenites and granites (Figure 2). Xenoliths of gabbroic (in monzodiorites) and monzonitic (in syenite, granites and monzonites) composition are observed in all these magmatic rocks. To better constraint the magmatic evolution of these rocks, 27 samples were selected for litho-geochemistry. Among which 09 deformed monzonites samples (JPS1, JPg5, JPg51, JPg1, JPSK-1; JPg33, JPS3, JPg48, JPg17) and 01 xenolith (JPg3); 04 samples (JPg41, JPg52, JPg26, JPS4) of monzodiorite and 02 xenoliths (JPg46, JPg42); 04 samples of granites (JPg30, JPg49, JPS6409, JPS809) and 02 xenoliths (JPg12, JPg13) and 04 sample of syenite (JPS59, JPg10, PNT2, PNT23) and 01 xenoliths (JPg36) for geochemical analyses. Results of these geochemical analyses are presented in Table 1.

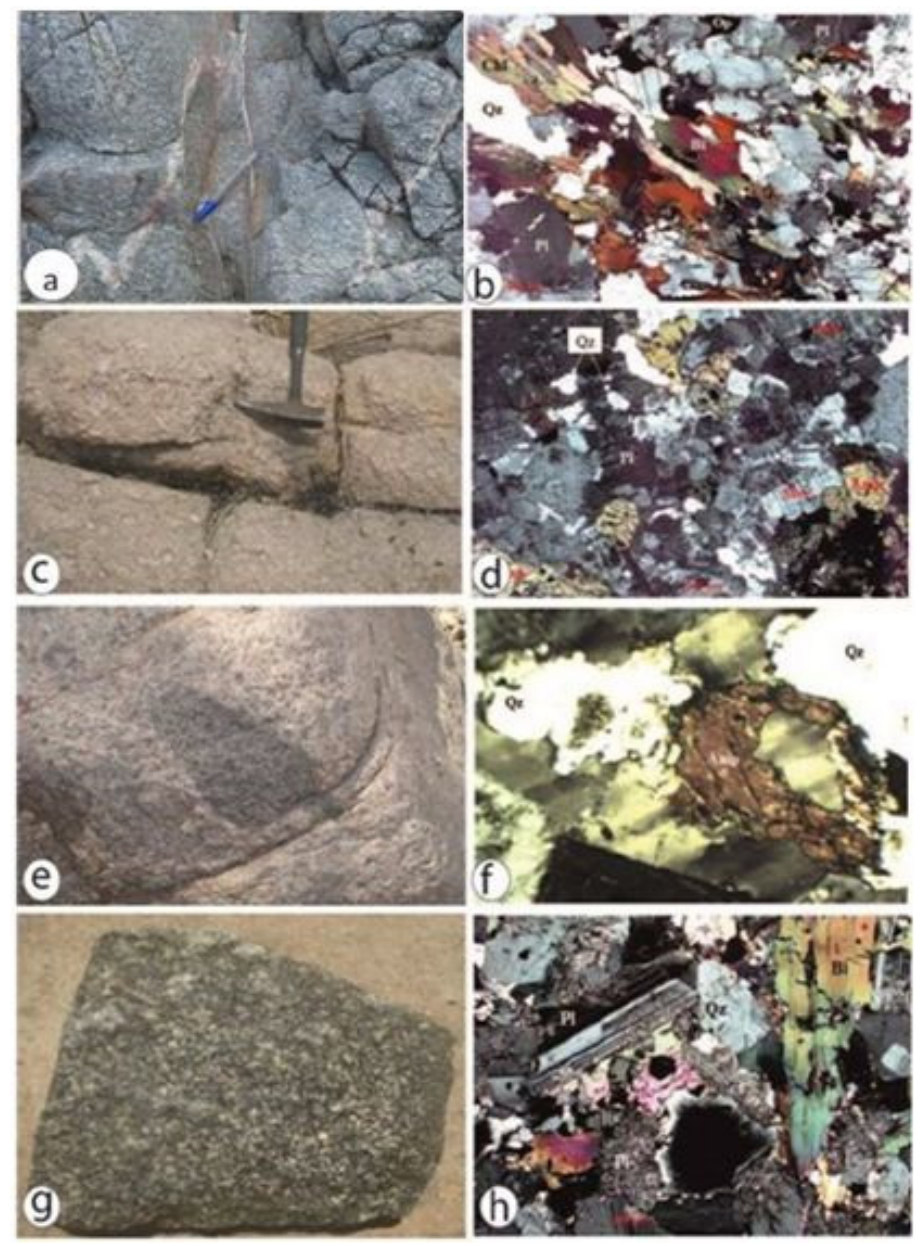

Figure 2. Macroscopic and microscopic view and composition of granitoids from the Boula Ibi region a-b deformed monzonite; c-d, syenite; e-f, granite; g-h, monzodiorite. $\mathrm{Qz}=$ quartz; $\mathrm{Pl}$ = plagioclase; $\mathrm{Bi}=$ biotite; Amp $=$ amphibole 
Table 1. Major and traces elements of Boula Ibi granitoids

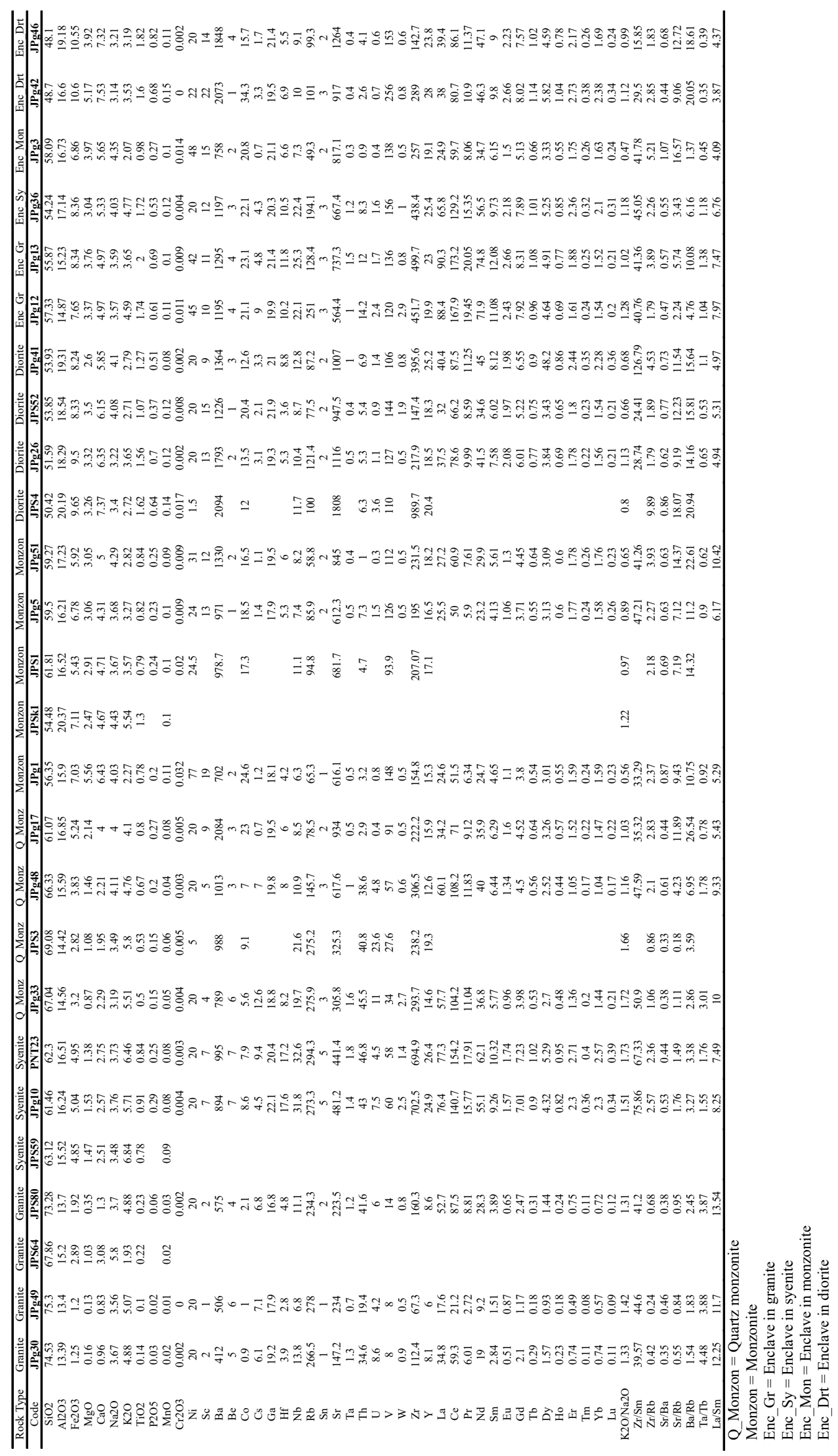




\subsection{Methods}

Petrographic analyses were made by microscopic observation and mineral modes determined by optical observation. For geochemical analysis, selected samples were cut in to cubes of $5 \times 3 \times 3 \mathrm{~cm}^{3}$ at the Centre of Geological and Mining Research of Garoua (Cameroon). Samples were ground in an agate mill. Major elements were determined by X-ray fluorescence spectrometry (XRF). Relative standard deviations (RSD) are within 5\%, and totals were within $100 \pm 1 \%$. REE, HFSE (Nb, Ta, Zr, Hf), and other trace elements were analyzed by Inductively Coupled Mass Spectrometry (ICP-MS) at the ACME laboratory Vancouver, Canada, using the protocol of Jenner et al. (1990), with standard additions, pure elemental standards for external calibration, and BIR-1 as a reference material. Detailed descriptions of analytical procedures and values obtained for reference materials are given in Fan and Kerrich (1997). Detection limits are $0.01 \%$ for major elements and $0.005-5 \mathrm{ppm}$ for trace elements. The results are presented in Table 1. Geochemical diagrams were realised with the GCDkit 3.00 software.

\section{Results}

\subsection{Petrography}

The Boula Ibi region consists of metamorphites in which are intruded four generations of granitoids; the orthogneiss of monzonitic composition; undeformed diorites, granites and syenites (Figure 1c).

\subsubsection{Banded Gneisses}

The banded gneisses extend as metric to hectometric outcrops easily accessible at Mayo Bangay, Babanguel, Boula Ibi, Ouro Kossi, Ouro Boussa and Yorko (Figure 1c). They include in outcrops, various gneisses and amphibolite layers. From mesoscopic to hand scales, they show pink, grey and dark rock colour with medium to coarse grained, highlight by centimetric to plurimetric layers of meso-, leuco- and melanosomes differentiated into anatectic granite, meta-diorites and amphibolite.

\subsubsection{Orthogneiss (Monzonites)}

Orthogneiss of monzonitic composition consist of continuous deformed large bodies from map to outcrop scales within banded gneisses (Figure 2). They crop out as large bands of NNE-SSW orientation in the Boula Ibi area. They are medium to coarse grained rocks of granoblastic texture (Figure 2a). Under the microscope (Figure 2b), they comprise plagioclase (35-40\%), quartz ( 20\%), amphibole (10-12\%), biotite (15-20\%), k-feldspar (8-10\%), chlorite and epidote $(\sim 2 \%)$. Zircon, apatite, sphene and iron-oxides are accessory. Plagioclase and quartz appear as anhedral either isolated stretched porphyroblasts or recrystallized fine blasts within the matrix. Biotite is in the form of large, contiguous oriented grains that emphasize foliation. It is often overgrown by chlorite. Amphibole is in the form of fine elongated crystals, sometimes associated with biotite.

\subsubsection{Diorites}

Diorites represented by the samples JPS4, occur at Djabi Boussa (Figure 1c), as a small massif oriented SW-NE; they are massive, dark, with hetero-granular texture locally marked by the orientation of feldspar and biotite crystals (Figure $2 \mathrm{~g}$ ) and enclosed numerous xenoliths of syn-tectonic monzonites. They exhibit a granular texture. The mineralogical composition is made of plagioclase $(25-30 \%)$, biotite $(\sim 22 \%)$, amphibole $(\sim 15 \%)$, quartz $(\sim 8 \%)$ and k-feldspar (4-6\%) (Figure 2h). Pyroxene is rare, while accessory minerals include apatite, sphene, zircon and oxides. Feldspar phenocrysts are euhedral affected by damouritization. Quartz appears as interstitial anhedral crystals. Amphiboles are subhedral phenocrysts, often zoned and associated with biotite or plagioclase with many inclusions of apatite and oxides. Biotite phenocrysts are folded and with zircon and oxides as inclusions. Accessory minerals, apatite, zircon and oxides occur mainly as inclusions in biotite and amphibole (Fig $2 \mathrm{~h}$ ).

\subsubsection{Syenites}

The Boula Ibi syenites crop out as NE-SW kilometric massif parallel to meta-monzonite. They consist of medium to coarse grained light to grey colour (Figure 2c). Under the microscope they are mainly composed of k-feldspar (52-55\%), quartz (10-12\%), plagioclase (15-18\%), amphibole (6-8\%) and biotite (10-12\%; Figure 2d). Sphene, zircon, allanite and apatite are found as accessory minerals. K-feldspars are subhedral crystals of variable sizes often enclosing quartz, albite and zircon. Quartz occurs either as anhedral phenocrystals or interstitial microcrystals. Plagioclase is rare and appears as subhedral microcrystals. Biotite and amphibole are isolated crystals or aggregates of a few individuals.

\subsubsection{Granites}

Boula Ibi granites occur as pink-coloured rock type, narrow elongated band in contact with syenites (Figs. 1c) and exhibit a coarse grained texture marked by abundant feldspar megacrysts $(0.5-1 \mathrm{~cm})$. They include quartz (27-30\%), k-feldspar (30-35\%), plagioclase (12-15\%), perthite (15-17\%), biotite (5\%) and amphibole (2-3\%). 
Accessory minerals include apatite, zircon, sphene, allanite and oxides (Fig 2f). Quartz appears either as isolated anhedral to subhedral mega, medium and fine crystals. K-feldspar is subhedral with straight lined contours. Plagioclase crystals are subhedral and sometimes alterated into damourite. Amphibole and biotite are isolated rare crystals. Inclusions of zircon are interstitial euhedral crystals.

\subsubsection{Xenoliths}

Xenoliths in general are dense, massive, dark gray in color, ovoid to elongate in shape and centimetric to decimetric in size. They are fragments of undeformed rock with a granular structure. They consist mainly of amphibole, biotite, pyroxene, plagioclase and quartz. Mineralogical proportions show that they are variable. The xenoliths observed in diorites have the composition of gabbro while those found in syenites, monzonites and granites have the composition of syenodiorites and monzonites.

\subsection{Geochemistry}

\subsubsection{Major Elements}

Major element concentrations of the Boula Ibi granitoids and their xenolites are listed in Table 1. Classification diagrams for plutonic rocks by Cox et al. (1979) show that the samples analyzed have a continuous composition of basic to intermediate and acidic rocks (Figure 3a). They are poor to rich in silica (with a total range of $48,1-75,31 \mathrm{wt} \% \mathrm{SiO}_{2}$ ) and show a high-K calc-alkaline and shoshonitic affinities except for sample JPS64 which portrays an intermediate potassic character (Figure $3 \mathrm{~b}$ ). $\mathrm{SiO}_{2}$ concentrations are low in all the xenolites $(48,1-58,09 \mathrm{wt} \%)$, in diorite $(50,42-53,93 \mathrm{wt} \%)$ and in monzonite $(54,48-59,5 \mathrm{wt} \%)$; medium in syenite $(61,46-66,43 \mathrm{wt} \%)$ and quartz rich monzonite $(61,07-69,09 \mathrm{wt} \%)$; high in granite $(67,81-75,31 \mathrm{wt} \%)$. The total alkali concentrations are high and slightly variable within each rock type, that is, $7,73-8,65 \mathrm{wt} \%$ in granite, $8,88-10,32 \mathrm{wt} \%, 8,1-9,57$ in quartz rich monzonite, 6,3-9,87 $\mathrm{wt} \%$ in monzonite, 6,12-6,89 $\mathrm{wt} \%$ in diorite and $6,4-8,80 \mathrm{wt} \%$ in enclaves. These rocks are k-rich with $\mathrm{K}_{2} \mathrm{O} / \mathrm{Na}_{2} \mathrm{O}$ ratios ranging from 0.33 to 1,96 . They display characteristics of high-K calc-alkaline to shoshonitic series as shown in a classification diagram of Frost et al. (2001) relative to $\mathrm{K}_{2} \mathrm{O}\left(\% \mathrm{wt}\right.$ ) vs $\mathrm{SiO}_{2}$ (Figure 3b). According to the Al saturation index $\mathrm{A} / \mathrm{CNK}=$ molar $\mathrm{Al}_{2} \mathrm{O}_{3} /\left(\mathrm{CaO}+\mathrm{Na}_{2} \mathrm{O}+\mathrm{K}_{2} \mathrm{O}\right)$ vs $\mathrm{Al}_{2} \mathrm{O}_{3} /\left(\mathrm{Na}_{2} \mathrm{O}+\mathrm{K}_{2} \mathrm{O}\right)$ (Chappell \& White, 1992), ranging between 0,7 and 1,1 , the analyzed granitoids are metaluminous to slightly peraluminous (granites) and correspond to I-Type granitoids (Figure 4c). There is no gap between basic and acidic granitoids suggesting that they may be cogenetic. In major variation diagrams of Harker, the Boula Ibi granitoids define more or less well trends, where $\mathrm{Al}_{2} \mathrm{O}_{3}, \mathrm{CaO}_{2} \mathrm{Fe}_{2} \mathrm{O}_{3}$, $\mathrm{MgO}, \mathrm{TiO}_{2}, \mathrm{P}_{2} \mathrm{O}_{5}$ and $\mathrm{MnO}$ concentrations decrease with increasing amount of $\mathrm{SiO}_{2}$, whereas the variation of $\mathrm{Na}_{2} \mathrm{O}$ and $\mathrm{K}_{2} \mathrm{O}$ is independent of the $\mathrm{SiO}_{2}$ variation (Figure 4a-h).
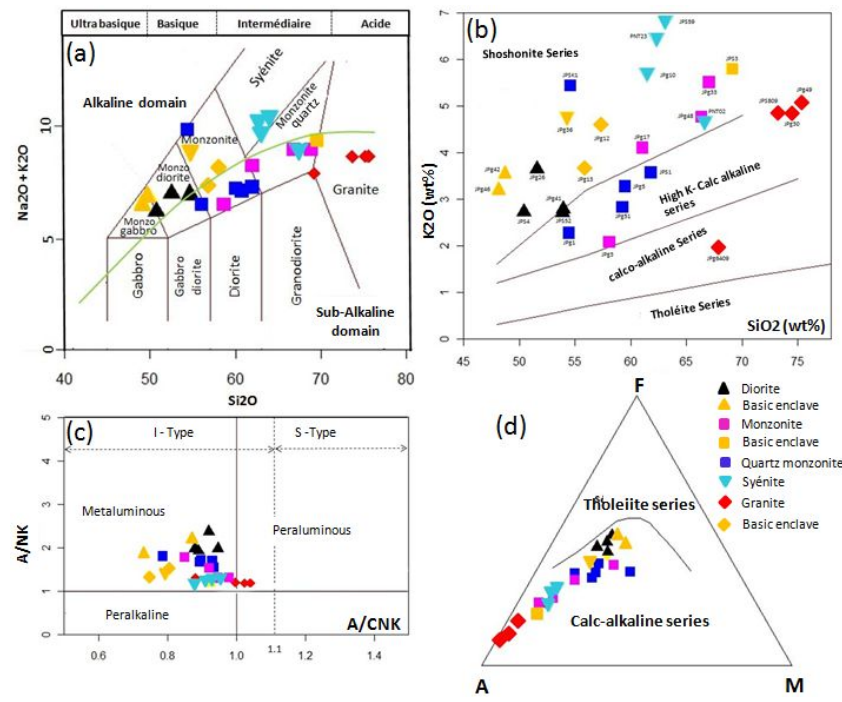

Figure 3. Classification diagrams of Boula Ibi granitoids

(a) Total alkali vs silica diagram (Middlemost, 1985); (b) Alkalinity $\left(\mathrm{K}_{2} \mathrm{O}\right.$ vs $\left.\mathrm{SiO}_{2}\right)$ diagram after Le Maitre et al., (1989), separing shoshonitic, calc-alkaline, high k- calc-alkaline and Tholeiitic domains of Boula Ibi granitoids; (c) A/Nk vs A/CNK molar diagrams after Maniar and Piccoli (1989). Dotted line shows boundary between S-type granite and I - type granite (Chappell et al., 1992); (d) A-F-M diagram of Irvine and Baragar (1968). A = $\mathrm{Al}_{2} \mathrm{O}_{3} ; \mathrm{C}=\mathrm{CaO} ; \mathrm{N}=\mathrm{Na}_{2} \mathrm{O}_{3} ; \mathrm{K}=\mathrm{K}_{2} \mathrm{O}$ 

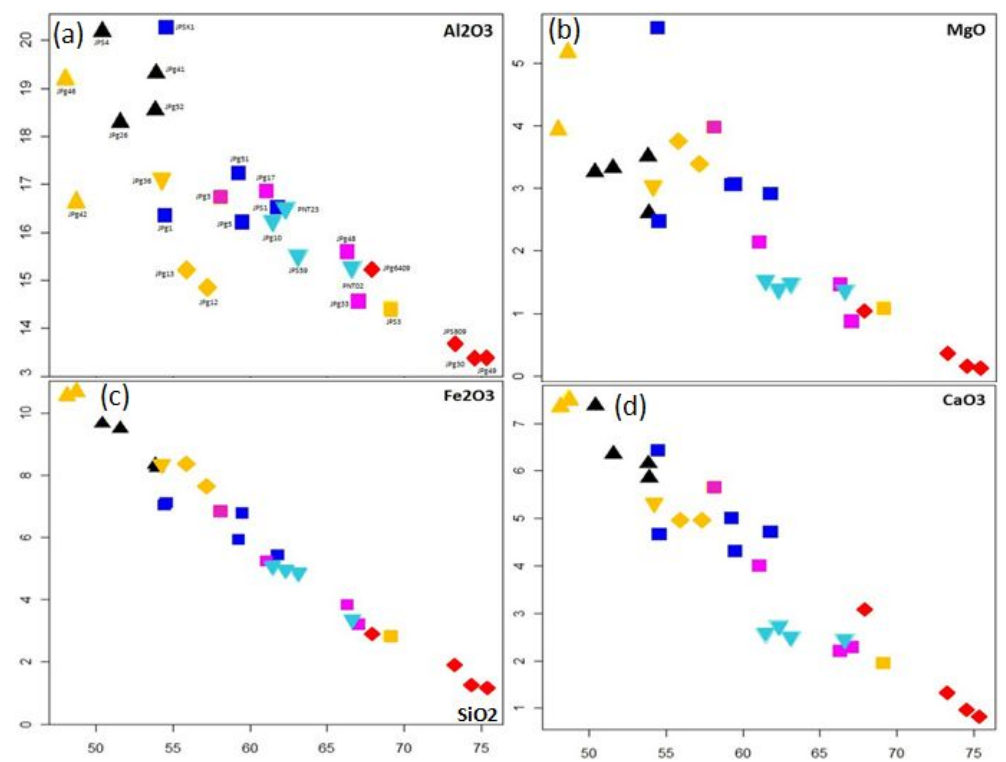

Figure 4a. Major elements vs $\mathrm{SiO}_{2}$ Harker variation diagram of the Boula Ibi region granitoids

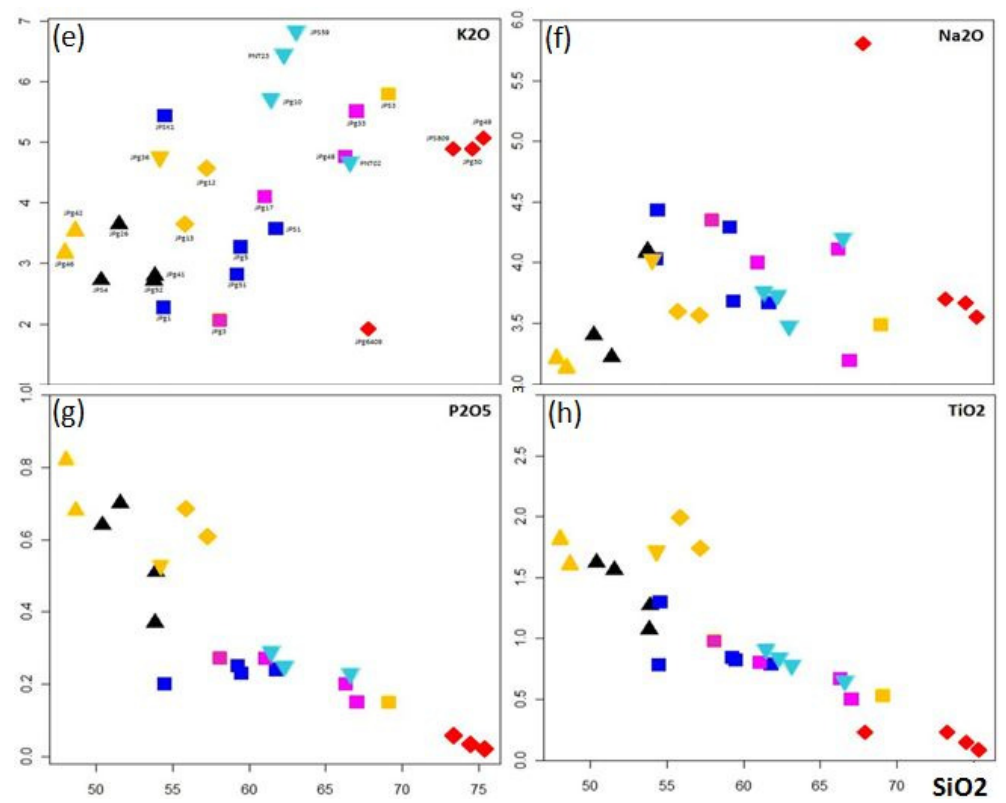

Figure 4b. Major elements vs $\mathrm{SiO}_{2}$ Harker variation diagram of the Boula Ibi region granitoids

\subsubsection{Trace Elements}

Trace elements concentrations of the Boula Ibi granitoids listed in Table 1 exhebit important variations. These concentrations are high in $\mathrm{Ba}, \mathrm{Rb}, \mathrm{Sr}, \mathrm{V}, \mathrm{Zr}$ and low in $\mathrm{Co}, \mathrm{Cs}, \mathrm{Ga}, \mathrm{Nb}, \mathrm{Th}, \mathrm{Ta}$ and $\mathrm{U}$. transitional element $(\mathrm{Ni}$, $\mathrm{Co}, \mathrm{V})$ concentrations are low in granites and syenites, moderate in quartz rich-monzonite and high in monzonites and diorites. $\mathrm{Rb}$ concentrations are high in acidic rocks (granites and syenites) and significantly very low in basic rocks (quartz monzonites, monzonites and diorites). The Harker diagrams for selected elements (Figure $5 \mathrm{a} ; 5 \mathrm{~b}$ ) show that $\mathrm{Ba}, \mathrm{Sr}, \mathrm{V}, \mathrm{Y}$ concentrations decrease when $\mathrm{SiO}_{2}$ content increases. In contrast $\mathrm{Rh}, \mathrm{Ta}$, $\mathrm{Zr}, \mathrm{Nb}$, Th and Ce concentrations increase with increasing concentration of $\mathrm{SiO}_{2}$. $\mathrm{U}$ and $\mathrm{La}$ concentrations are scattered on Harker diagrams. $\mathrm{Ba} / \mathrm{Sr}$ ratios vary from 1,15 to 3,03 and $\mathrm{Ba} / \mathrm{Rb}$ between 1,54 and 22,61 these ratios are compatible with those observed in continental calc-alkaline igneous suites (Bertrand et al., 1984; Ayuso \& Arth, 1992). $\mathrm{Rb} / \mathrm{Sr}$ ratios increase from the low to the high silica concentration rocks. 

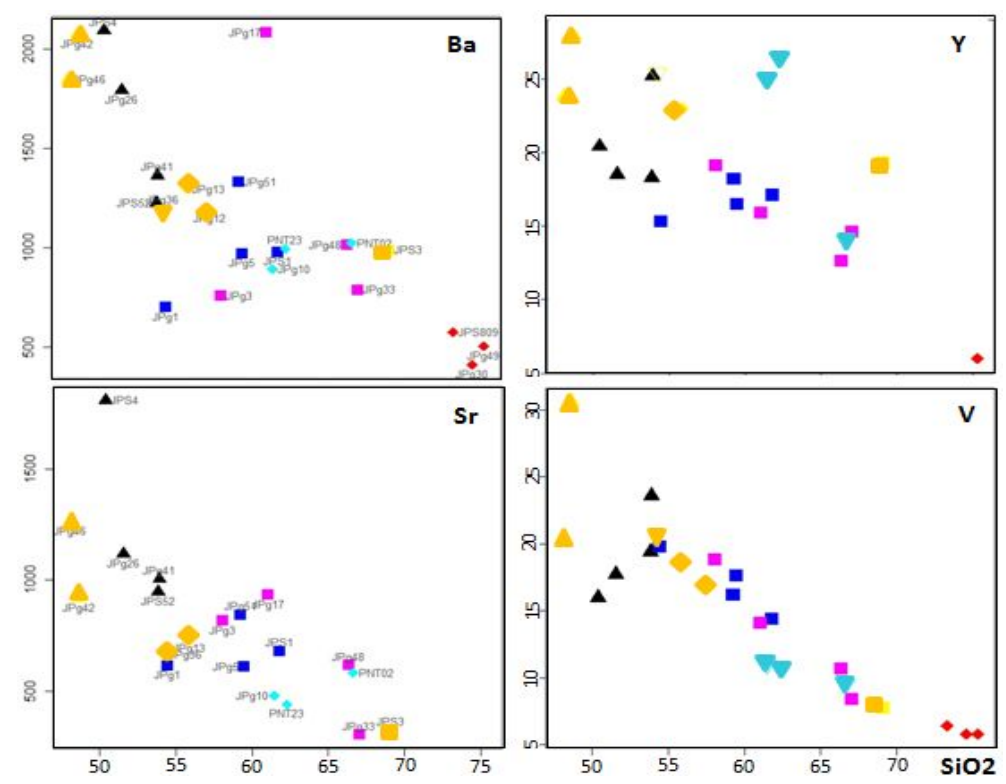

Figure 5a. Trace elements versus $\mathrm{SiO}_{2}$ Harker variation diagram of the Boula Ibi region granitoids

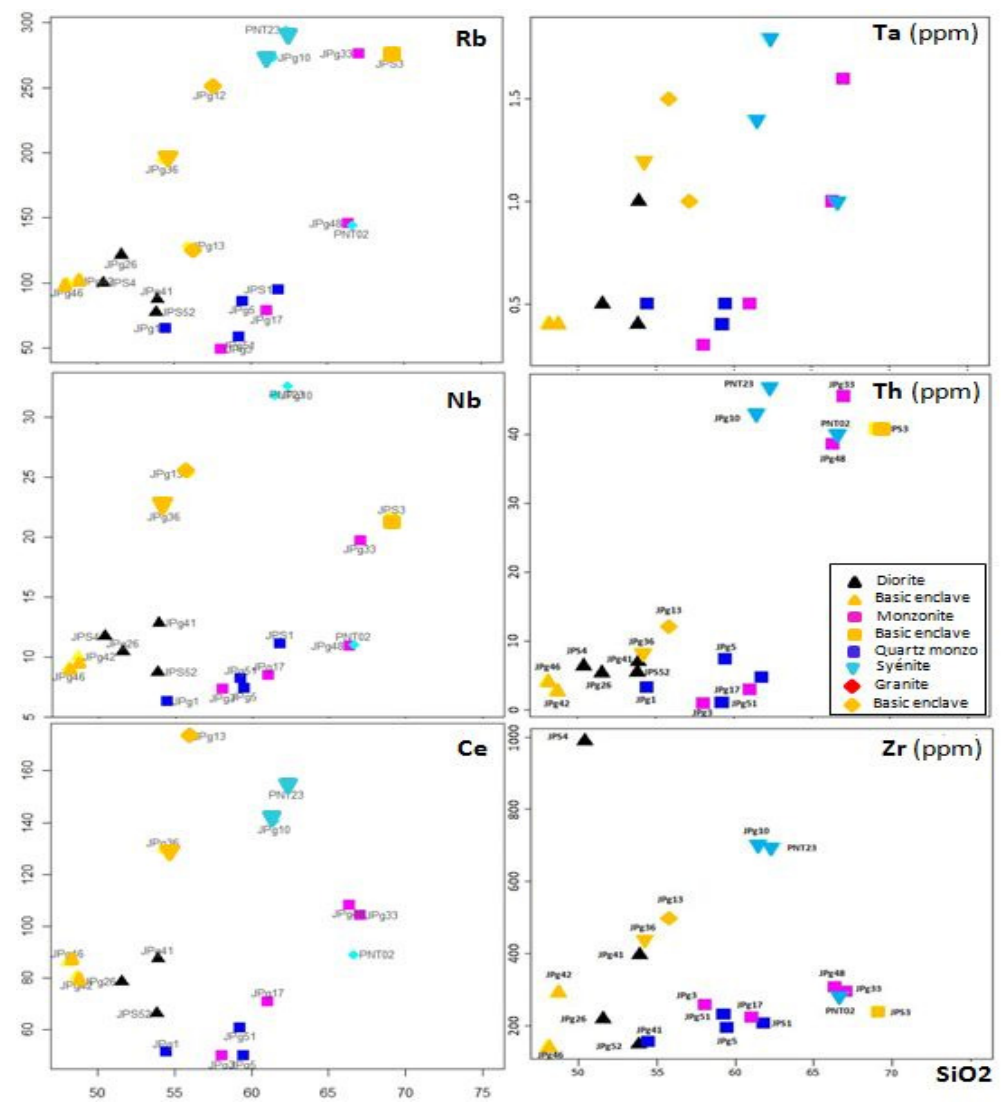

Figure $5 b$. Trace elements versus $\mathrm{SiO}_{2}$ Harker variation diagram of the Boula Ibi region granitoids

\subsubsection{Rare Earth Elements}

REE pattern of granitoids from the Boula Ibi area normalized to chondrites are similar. Generally, they show enrichment in LREE and depletion in HREE typical of calc-alkaline rocks (Figure 6a; 6c; 6e; 6g; 6i; 6k). 


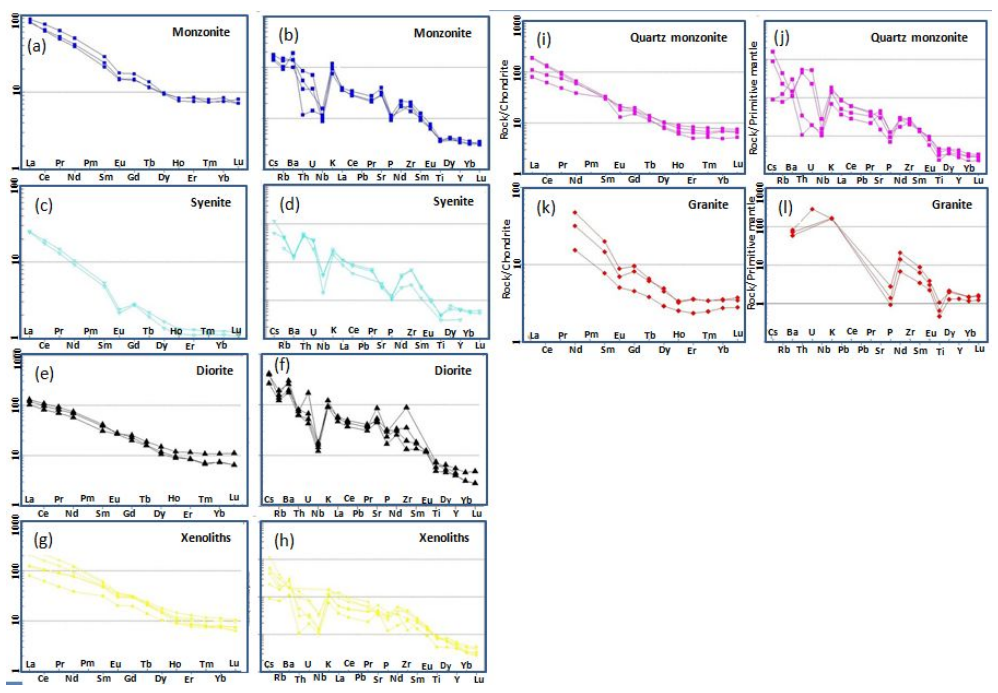

Figure 6. Rare earth elements and multi element variation spidergrams for the Boula Ibi region granitoids

Deformed monzonite display identical REE patterns with a weak anomaly in $\mathrm{Eu}\left(\mathrm{Eu} / \mathrm{Eu}^{*}=0.62-0.92\right)$. These patterns show depletion in LREE and almost constant tendency for HREE. $(\mathrm{La} / \mathrm{Yb})_{\mathrm{N}}$ ratios vary between 10.30 and 38.53 (10.30 - 10.76 for monzonite and 15.51 - 38.53 for quartz monzonite) indicating that deformed quartz monzonite are more fractionated than deformed monzonite. $(\mathrm{Eu} / \mathrm{Yb})_{\mathrm{N}}$ values range from 1.9 to 3.68 in both facies of monzonite and $(\mathrm{Ce} / \mathrm{Sm})_{\mathrm{N}}$ ratio of $2.55-4.24$ reflecting a proportionate fractionation in LREE and HREE. The primitive mantle normalized incompatible element patterns (Figure 6b; 6j) are homogenous. They display negative anomalies in $\mathrm{Ba}, \mathrm{Th}, \mathrm{Nb}, \mathrm{Ta}$ and $\mathrm{Ti}$.

Diorite samples have similar REE patterns (Figure 6f) with weak Eu anomalies (0.83 - 0.95) for samples JPg41 and $\mathrm{JPg} 26\left(\mathrm{SiO}_{2}=51.59-53.85 \%\right)$ and a positive Eu anomaly $\left(\mathrm{Eu} / \mathrm{Eu}^{*}=1.08\right)$ for sample $\mathrm{JPg} 52(\mathrm{SiO} 2=$ 53.85). the evolution of diorite with negative Eu anomaly to diorite with positive anomaly is accompanied by REE depletion. ( $\Sigma$ REE $=212.81$ and 192.33 for samples JPg41 and JPg26; $\Sigma$ REE $=163.21$ for JPg52). The ratio $(\mathrm{La} / \mathrm{Yb})_{\mathrm{N}}$ varies between 11.81 and 16.03 a clear indication of REE fractionation. The $(\mathrm{Eu} / \mathrm{Yb})_{\mathrm{N}}$ ratio ranges between 2.48 and 3.81 and $(\mathrm{Ce} / \mathrm{Sm}) \mathrm{N}$ between 2.43 and 2.58 all vary in similar ways and indicate a fractionation in minerals that incorporate HREE in their crystal structures (Sphene and zircon) likewise for those incorporating LREE (Apatite). Low proportions of $\Sigma$ REE alongside the slight and/or absence of Eu anomaly is attributed to the crystallization of apatite, amphibole and/or plagioclase accumulation. The primitive mantle normalized incompatible element pattern of diorite (Figure 6f) show enrichment in LILE relative to HFSE. Negative anomalies are observed in $\mathrm{Ba}, \mathrm{Th}, \mathrm{Nb}$, Ta and $\mathrm{Ti}$.

The sum of REE is higher in Syenite samples $(\Sigma$ REE $=317.12 \mathrm{ppm}-344.13 \mathrm{ppm})$. Its REE pattern shows enrichment LREE than in HREE with a moderate Eu anomaly $\left(\mathrm{Eu} / \mathrm{Eu}^{*}=0.60-0.62\right)$. This anomaly should be noted weaker in other rock samples. $(\mathrm{La} / \mathrm{Yb})_{\mathrm{N}}$ ratios vary between 20.05 and 22.14 a clear indication of REE fractionation. $(\mathrm{Eu} / \mathrm{Yb})_{\mathrm{N}}$ ratios vary between 1.93 and 1.95 whereas $(\mathrm{Ce} / \mathrm{Sm})_{\mathrm{N}}$ are high, with values from 3.51 to 3.57 indicating an important fractionation in LREE than in HREE. Eu anomalies are higher in syenite than in other rock samples indicating a simultaneous crystallization of plagioclase and alkaline feldspars. The primitive mantle normalized incompatible elements (Figure 6d) show negative anomalies in $\mathrm{Ba}, \mathrm{K}, \mathrm{Nb}, \mathrm{Ta}, \mathrm{Sr}, \mathrm{P}$ and Ti.

REE patterns of granite are similar (Figure 6k) and present a moderate to weak Eu anomaly $(0.64-0.86)$ with linear depletion from LREE to HREE. The sum of REE for samples JPg09 and JPg30 stands at $188.01 \mathrm{ppm}$ and $128.35 \mathrm{ppm}$ respectively and very low in sample JPg49 (56.29 ppm). (La/Yb) $)_{\mathrm{N}}$ ratios vary between 20.58 and 48.8 showing an important degree of fractionation of REE (Figure 61). $(\mathrm{Eu} / \mathrm{Yb})_{\mathrm{N}}$ values range from 1.85 to 2.58 with little significance as compared to $(\mathrm{Ce} / \mathrm{Sm})_{\mathrm{N}}$ ratio ranging between 3.29 and 5.28 indicating an important degree of fractionation of minerals that incorporate LREE (apatite) than those that incorporate HREE. The primitive mantle normalized incompatible elements show negative anomalies in $\mathrm{Ba}, \mathrm{Nb}, \mathrm{Sr}, \mathrm{P}$ and $\mathrm{Ti}$.

Basic xenolites trapped in the granitoids of the Boula Ibi have variable REE concentrations. Xenolites of more evolve rocks (granite and syenite) have higher REE concentrations ( $\Sigma \mathrm{REE}=378.56) . \quad \Sigma \mathrm{REE}=392.02 \mathrm{ppm}$ for xenolites in granites, $298.95 \mathrm{ppm}$ in syenite, $210.17 \mathrm{ppm}$ and $213.52 \mathrm{ppm}$ in diorite and $148.63 \mathrm{ppm}$ in deformed 
monzonite. The REE patterns show enrichment in LREE. This enrichment is more pronounced in granites and syenites. Eu anomalies are slightly negative $\left(\mathrm{Eu} / \mathrm{Eu}^{*}=0.67-0.82\right.$ in granites; 0.76 in syenite). $(\mathrm{La} / \mathrm{Yb})_{\mathrm{N}}$ stand at $38.27-39.61$, and 20.89 for xenolites in granites and syenites respectively; $10.64-15.54$ in diorite and 10.38 in deformed monzonite. These results show fractionation in REE in xenoliths of acidic rocks and a moderate one for basic rocks. $\mathrm{Ce}_{\mathrm{N}} / \mathrm{Sm}_{\mathrm{N}}$ and $\mathrm{Eu}_{\mathrm{N}} / \mathrm{Yb}_{\mathrm{N}}$ ratios show little variations $\mathrm{Ce}_{\mathrm{N}} / \mathrm{Sm}_{\mathrm{N}}$ and $\mathrm{Eu}_{\mathrm{N}} / \mathrm{Yb}_{\mathrm{N}}$ values stand at 3.36 -3.56 and $3.77-5$ respectively in granites; 3.12 and 2.97 in syenite, 2.28 and 2.63 in deformed monzonite; 1.93 -2.25 and $3.17-3.19$ in monzodiorites). These characteristics are indicative of strong plagioclase fractionation (weak Eu/Eu* anomaly) and a proportionate fractionation in neighbouring HREE and LREE $\left(\mathrm{Ce}_{\mathrm{N}} / \mathrm{Sm}_{\mathrm{N}}\right.$ and $\mathrm{Eu}_{\mathrm{N}} / \mathrm{Yb}_{\mathrm{N}}$ ) of zircon, sphene and apatite. The primitive mantle normalized incompatible element patterns (Figure $6 \mathrm{~h}$ ) are homogenous. They display negative anomalies in $\mathrm{Ba}, \mathrm{Th}, \mathrm{Nb}, \mathrm{Ta}, \mathrm{Sr}, \mathrm{P}$ and Ti.

\section{Discussion}

The studied Boula Ibi granitoids exhibit chemical compositions characteristic of metaluminous to weakly peraluminous (Figure 3c), high-K calc-alkaline to shoshonitic rocks (Figure 3b: Chappell et al., 1992; Chappell et al., 1974). Such rocks derive from partial melting of igneous metaluminous protoliths relativily rich in potassium (Robert \& Clemens, 1993). In addition their behavior on Harker diagrams indicate continuous variations from basic to acidic rocks showing a negative correlation with linear tendency for $\mathrm{Al}_{2} \mathrm{O}_{3}, \mathrm{MgO}, \mathrm{CaO}$, $\mathrm{TiO}_{2}, \mathrm{Fe}_{2} \mathrm{O}_{3}$ and $\mathrm{P}_{2} \mathrm{O}_{5}$, and a positive correlation with $\mathrm{K}_{2} \mathrm{O}$ (Figure $4 \mathrm{a} ; 4 \mathrm{~b}$ ). $\mathrm{Sr}$ and $\mathrm{Ba}$ concentrations are compatible and decrease with increasing concentrations in $\mathrm{SiO}_{2}$ (Figure 5a). $\mathrm{Sr} / \mathrm{Ba}$ ratios slightly vary $(0,33-$ 1,07), whereas $\mathrm{Rb} / \mathrm{Sr}$ ratios increase strongly $(0,055-1,81)$ with increasing concentrations of $\mathrm{SiO}_{2}$. These charateristics are compatible with magma evolution by fractional crystallization (Figure 7b; Bowden et al., 1974; Provost \& Allegre, 1979) of basic to acidic magma and indicate that the fractionation of plagioclase and $\mathrm{K}$-feldspar was the important mechanism in the course of the magmatic evolution of the I-Type granitoids (Djouka-Fonkwé et al., 2008). According to Stephen (2006) diagrams of ratios of high to slightly incompatible elements $\mathrm{La} / \mathrm{Sm}$ vs incompatible elements $\mathrm{La}$, generate almost linear depicting for fractional crystallization and high gradient lines showing partial melting.

The studied granitoids show high concentrations in LILE (e.g., Ba, Rb), depletion in HFSE (Cs, Ta, Nb, Tb, Hf), relatively low ratio of $\mathrm{Nb} / \mathrm{La}(0,18-0,42)$ but high ratio of $\mathrm{Ba} / \mathrm{La}(10,91-60,93)$ similar with granitoids from Central Iforas (Bertrand et al., 1984). The increase in the rate of mantle fusion produces melt poor in incompatible elements. According to Rapp and Watson (1995), high rate of partial melting from 20 to $40 \%$ of mafic rocks will give rise to melts of basic to intermediate compositions with high concentrations in $\mathrm{Al}_{2} \mathrm{O}_{3}$. $\mathrm{The}$ spider diagrams characteristically display negative anomalies for $\mathrm{Ba}, \mathrm{Sr}, \mathrm{Ti}$, and $\mathrm{Nb}$. These anomalies result from either the low content of these elements in the source or their retention in the residue during partial melting.

The Boula Ibi granitoids have high $\mathrm{K}_{2} \mathrm{O}$ concentrations. $\mathrm{K}$ enrichment might be favoured by melting of lithospheric mantle that constitutes a huge reservoir of readily available K-rich component (Liégeois et al., 1998). However the high and variable contents of lithophile elements, highly variable elements ratios and the lack of correlation among these elements indicate that fractional crystallization or variable degrees of partial melting of the same source cannot explain the relationship among the various granitoids on its own. Compositional differences of melts produced by partial melting of different source rocks under variable melting conditions can be visualized in terms of molar $\mathrm{CaO} /(\mathrm{MgO}+\mathrm{FeOtotal})$ vs molar $\mathrm{Al}_{2} \mathrm{O}_{3} /\left(\mathrm{MgO}+\mathrm{FeO}_{\mathrm{t}}\right)$ diagram (Altherr et al., 2000). In this diagram, most of the samples of the granite plot in the field of partial melts from metagreywackes while those of diorite, monzonite, quartz monzonite and syenite plot in the field of partial melting from metabasaltic to metatonalitic sources (Figure 7c). Similar sources are found to the granitoids from many Pan-African domains in Cameroun (Djouka-Fonkwé et al., 2008; Kouankap et al., 2010; Nzolang et al., 2003; Nguiessi et al., 1994; Tagne-Kamga et al., 2003) eastern Nigeria and NE Brazil. These source rocks are predominantly found in the upper part of the lithospheric mantle and/or lower part of continental crust and we suggest that the source for the diorite, monzonite, quartz-monzonite and syenite was metamorphosed upper mantle and lower crustal mafic igneous rocks. However, the absence of isotopic data makes it impossible to draw a definitive conclusion as to this source material.

The Boula Ibi granitoids occur in a high-grade gneiss bloc (Figure 1c). The Rb/30-Hf-Ta/3 tectonic discrimination diagram of granitoid rocks allows the discrimination of the analysed granitoids into three major groups, i.e. post collision uplift, late-orogenic and post-orogenic (Figure 7a). Basic rocks (diorite, monzonite, xenoliths) plot in post collision uplift field, whereas intermediate and acidic rocks plot respectively in the late orogenic (syenite) and post orogenic fields (granite). 


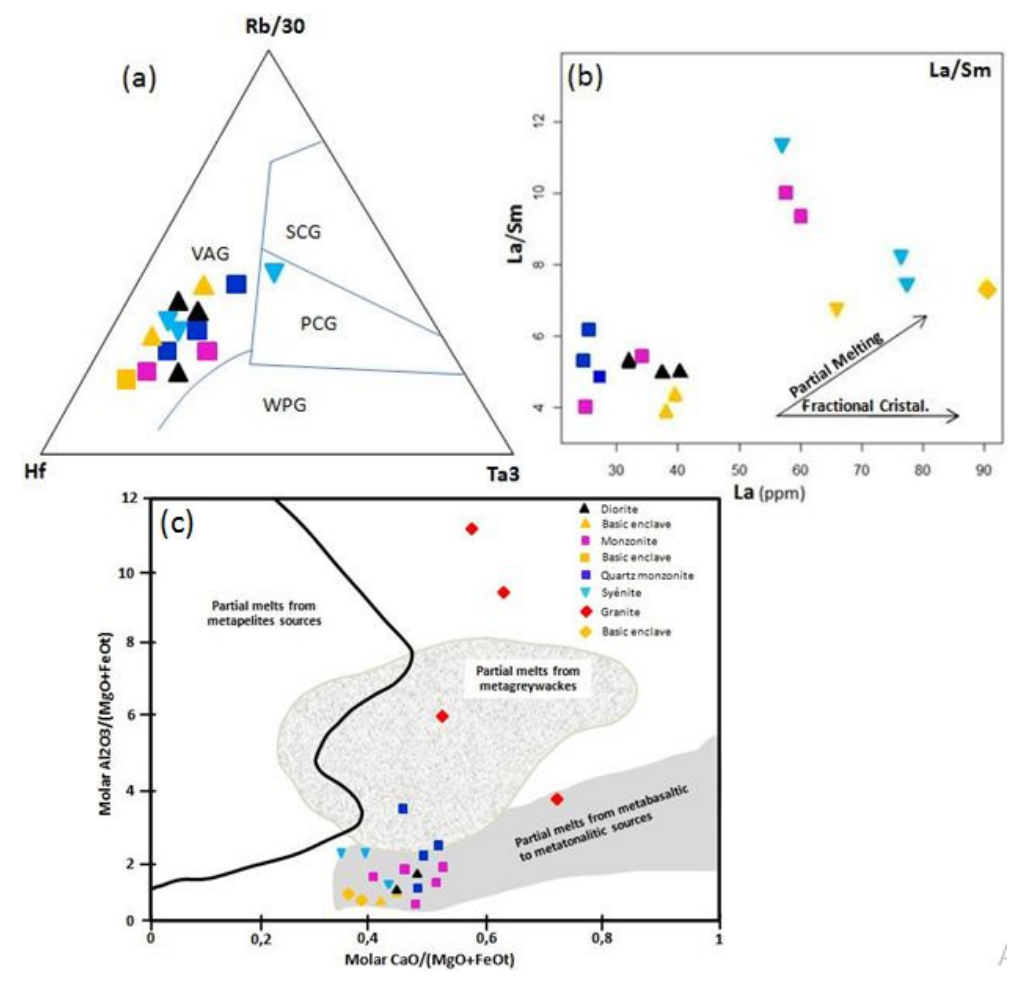

Figure 7. (a) Hf-Rb/3-Ta3 diagrams of geotectonic settings of the Boula Ibi granitoids (Harris et al., 1986), VAG = volcanic arc granitoids; syn-COLG = Syn- Collisional Granitoids; post-COLG = Post Collisional Granitoids; WPG = Within Plate Granitoids; ORG: Oceanic Ridge Granitoids; (b) Characterization of geologic processes (fractional crystallization and partial melting) and source determination of the analyzed granitoids using $\mathrm{La} / \mathrm{Sm}$ vs La diagram; (c) Molar $\mathrm{CaO} /(\mathrm{MgO}+\mathrm{FeOt})$ versus $\mathrm{Al}_{2} \mathrm{O}_{3} /(\mathrm{MgO}+\mathrm{FeOt})$ for the Boula Ibi granitoids showing magmatic sources of the Boula Ibi granitoids

High-K calc-alkaline series evolve during the late stage of the orogeny to particularly enriched potassic facies, occasionally shoshonitic in continental collision setting (Liégeois et al., 1998). Two main processes are commonly known to constrain the generation of high-K magmas in those convergent tectonic settings (Altherr et al., 2000): (a) in continental arc settings, where mantle melts can be enriched by slab-derived fluids and further may become contaminated with crustal material during ascent (De Paolo, 1981); (b) in syn to post collisional settings, where crustal source rocks melt as a consequence of decompression following delamination of the lithospheric root or slab break off (Roberts \& Clemens, 1993; Liégeois et al., 1994).

In orogenic domains, structures such as foliations, thrust planes and shear zones, and their directions of dip are probably inherited from earlier collision episodes (Allmendiger et al., 1987). Crustal-scale shear zones are suitable to tap magma at different depths, and magma upward migration is achieved by density contrast and by sucking due to the strike-slip movement along shear zones (D'Lemos et al., 1992). In addition, post-collisional period is characterized by the large movements of terranes along shear zones and the rise of regional isotherms (Liégeois et al., 1998).

The Boula Ibi region is located to the nothern part of the Pan-African domain in Cameroon (Figure 1b). This domain is limited farther to the west by Trans-Sahara-Nigeria domain that includes dextral submeridional and NE-SW synthetic shear zones cross-cutting earlier fold and thrust zones (Ngako et al.; 2008; Ferré et al., 1998). At the regional scale, the collision model of Ngako et al. (2008) suggests that tectonic events througout the Pan-African domains and respective kinematics allow determination of regional strain field compatible with the evolution of tectonic indent in northwestern Cameroon. Related shear zones both in Trans-Sahara-Nigeria and Cameroon-Oubanguides provinces were over printed by right lateral shear movements during a late clockwise rotation of northwestern Cameroon (Ngako et al., 2008).

Major element geochemistry of Boula Ibi granitoids points to the high-K shoshonitic and calc-alkaline affinity of the investigated samples, implying a subduction-to collision-related geotectonic setting. Structural field observations marked by the conformity of structures (strike and dip of foliation and shear zones) both in the 
deformed granitoids and basement rocks indicate that the emplacement of Boula Ibi granitoids along dextral shear zone $\mathrm{N} 45^{\circ} \mathrm{E}$ was synchronous and late to post tectonic $\left(\mathrm{D}_{2}\right)$. In addition, the fact that basic to intermediate facies (deformed monzonite, diorite) of Boula Ibi granitoids are slightly or strongly deformed whereas acidic facies (granite and syenite) are undeformed suggests that syn-magmatic deformation might have been essential for enhancing the differentiation mechanism (Bea et al., 2005).

These data are consistent with results of previous studies (Penaye et al., 2006; Isseini et al., 2011) which define the northern Cameroon as a magmatic arc of Pan-African age associated to a collision between Mayo Kebbi and west Cameroon domains. Similar syntectonic features are found in the neighbouring Pan-African plutons in Nigeria (Ferré et al., 1998; Deleris et al., 1996) and in Cameroon (Tchameni et al., 2015; Dawaï et al., 2013; Kouankap et al., 2010).

\section{Conclusions}

The granitoids of Boula Ibi region are magmatic rocks mainly composed of deformed monzonites, hosting diorites, syenites and granites. All these granitoids are bearing basic xenoliths of dioritic to monzonitic composition. Among these granitoids only the deformed monzonites have undergone deformation. Field observations and petrographic analysis point the fact that these deformed rocks are intrusives in gneisses host and syntectonic of $\mathrm{D}_{2}$ phase of deformation in this region.

All the rock types are strongly metaluninous to weackly peraluminous (granites), high-K calc-alkaline and shoshonitic, and conform to I-type granitoids, that derive from partial melting of igneous metaluminous protoliths relativily rich in potassium. However molar $\mathrm{CaO} /(\mathrm{MgO}+\mathrm{FeOt})$ vs $\mathrm{Al}_{2} \mathrm{O}_{3} /\left(\mathrm{MgO}+\mathrm{Al}_{2} \mathrm{O}_{3}\right)$ diagram used to point compositional differences of melt produced by partial melting of differents sources shows that these granitoids come from melting of different sources.

Geochemical features marked by: 1) increasing concentrations of $\mathrm{SiO}_{2}$ from basic to acidic rocks; 2) major elements behavior indicating, negative correlations between $\mathrm{Al}_{2} \mathrm{O}_{3}, \mathrm{MgO}, \mathrm{CaO}, \mathrm{TiO}_{2}, \mathrm{Fe}_{2} \mathrm{O}_{3}, \mathrm{P}_{2} \mathrm{O}_{5}$ and $\mathrm{SiO}_{2}: 3$ ) $\mathrm{Sr} / \mathrm{Ba}$ ratios, $\mathrm{Rb} / \mathrm{Sr}$ variations with varying concentrations of $\mathrm{SiO}_{2}$ point for magma evolution by fractional crystalisation of basic to acidic rocks and indicate that the fractionation of plagioclase and K-feldspar was the main mechanism in the course of magmatic evolution. In addition, $\mathrm{La} / \mathrm{Sm}$ vs La diagram demonstrate that partial melting and crystal fractionation were the main process in magmatic evolution.

Field structural observations and previous works data in the Pan-African northern domain of Cameroon and neighbouring domains of western Tchad and eastern Nigeria show that the Boula Ibi granitoids were emplaced following a dextral shearing tectonic concecutive to a collision between western african craton, the Sao-Francisco Congo craton and the eastern Saharan block during the Pan African orogeny.

\section{Conflict of interests}

The authors declare that there is no conflict of interests regarding the publication of this paper.

\section{Reference}

Abdelsalam, M. G., Liégeois, J. P., \& Stern, R. J. (2002). The Saharan Metacraton. Journal of African Earth Sciences, 34, 119-136.

Allmendinger, R. W., Hauge, T. A., Hauser, E. C., Potter, C. J., \& Olivier, J. (1987). Tectonic heredity and the layered lower crust in the Basin and Range Province, Western United States, continental extensional tectonics (pp. 223-246). London, Geological Society Special Publication.

Altherr, F. F., Holl, A., Hegner, E., Langer, C., \& Kreuzer, H. (2000). High-potassium, calc-alkaline I-type plutonism in the European variscides: northern Vosges (France) and northern Schwarzwald (Germany). Lithos, 50, 51-73.

Ayuso, R. A., \& Arth, J. G. (1992). The Northeast Kingdom batholith, Vermont: Magmatic evolution and geochemical constraints on the origin of Acadian granitic rocks. Contribution to Mineralogy and Petrology, 111(1), 1-23.

Barbarin, B. (1999). A review of the relationships between granitoids types, their origins and their geodynamic environments. Lithos, 46, 605-626.

Bassahak, J. (1988). Le complexe plutonique du massif de Kogué (Poli, Nord Cameroun): Pétrologie, géochimie, pétrologie structurale. Sa place dans le plutonisme de la chaîne panafricaine du Nord Cameroun. Thèse de Doctorat de l'Université de Nancy I, 259.

Béa, A. (1986). Grabens et volcanisme tholéitique continental associé, d'âge ordovicien-dévonien probable, 
dans la région de Garoua, au Nord Cameroun (p. 170). Thèse de Doctorat de 3e cycle, Université d'Aix-Marseille III.

Bea, A., Cochemé, J. J., Trompette, R., Affaton, P., Soba, D., \& et Sougy, J. (1990). Grabens d'âge Paléozoïque inférieur et volcanisme tholéiitique associé dans la région de Garoua, Nord Cameroun. Journal of African Earth Sciences, 10, 657-667.

Bea, F., Fershtaterb, G. B., Monteroa, P., Smirnovb, V. N., \& Molina, J. F. (2005). Deformation-driven differentiation of granitic magma: The Stepninsk pluton of the Uralides, Russia. Lithos, 81, 209-233.

Bertrand, J. M., Dupuy, C., Dostal, J., \& Davison, I. (1984). Geochemistry and geotectonic interpretation of granitoids from Central Iforas (Mali W. Africa). Precambrian Res., 26, 265-283.

Bouyo Houketchang, M., Zhao, Y., Penaye, J., Zhang, S. H., \& Njel, U. O. (2015). Neoproterozoic subduction-related metavolcanic and metasedimentary rocks from the Rey Bouba Greenstone Belt of north-central Cameroon in the Central African Fold Belt: New insights into a continental arc geodynamic setting. Precambrian Research, 261, 40-53.

Bowden, P., \& Whitley, J. E. (1974). Rare earth's pattern in peralkaline and associated granites. Lithos., 7, 15-23.

Castaing, C., Feybesse, J. L., Thiéblemont, D., Triboulet, C., \& Chèvremont, P. (1994). Palaeogeographical reconstructions of the Pan-African/Brasiliano orogen: Closure of an oceanic domain or intracontinental convergence between major blocks? Precam. Res., 69, 327-344.

Chappell et al. (1974). Two contrasting granite types. Pacific Geology, 8, 173-174.

Chappell, B. W., \& White, A. J. R. (1992). I and S-type granites in the Lachlan Fold Belt. Transactions of the Royal Society of Edinburgh: Earth Sciences, 83, 1-26.

Cox, K. G., Bell, J. D., \& Pankhurst, R. J. (1979). The Interperatation of Igneous Rocks. George Allen and Unwin, London.

D’Lemos, B. M., \& Strachan, R. A. (1992). Granite magma generation, ascent and emplacement within a transpressional orogen. J. Geol. Soc. London, 149, 487-490.

Dawaï, D. (2014). Les plutons de Guider et de Bossoum-Pologozom (chaîne Panafricaine au Nord-Cameroun): Analyse pétrographique, structurale, magnétique, géochronologique et implications géodynamiques (p. 208). Thèse de Doctorat de l'Université de Toulouse.

Dawaï, D., Bouchez, J.-L., Paquette, J.-L., \& Tchameni, R. (2013). The PanAfrican quartz-syenite of Guider (north-Cameroon): magnetic fabric and $\mathrm{U}-\mathrm{Pb}$ dating of a late-orogenic emplacement. Precambrian Res, 236, 132-144.

De Paolo, D. J. (1981). Trace Element and Isotopic Effects of Combined Wallrock Assimilation and Fractional Crystallization. Earth and Planetary Science Letters, 53, 189-202.

Déléris, J., Nédélec, A., Ferré, E., Gleize, G., Ménot, R. P., Obasi, C. K., \& Bouchez, J. L. (1996). The Pan-African Toro Complex (northern Nigeria): Magmatic interactions and structures in bimodal intrusion. Geological Magazine, 133, 535-552.

Djibril, K. N. G., Paul, N. J., Suh, C. E., \& Sylvestre, G. (2010). Geochemistry of Ferriferous, High-K Calc-Alkaline Granitoids from the Banefo-Mvoutsaha Massif (NE Bafoussam), Central Domain of the Pan-African Fold Belt, Cameroon. The Open Geology Journal, 2010, 4, 15-28.

Djouka-Fonkwe, M. L., Schulz, B., Schüssler, U., Tchouankoué, J.-P., \& Nzolang, C. (2008). Geochemistry of the Bafoussam Pan-African I- and S-type granitoids in western Cameroon. Journal of African Earth Sciences, 50(2008), 148-167.

Doumnang, J. C. (2006). Géologie des formations néoprotérozoïques du Mayo Kebbi (sud ouest du Tchad): Apports de la pétrologie et de la géochimie, implications sur la géodynamique au Panafricain (p. 223). Orléans, Université d'Orléans.

Ekwueme, B. N., \& Kröner, A. (1997). Zircon evaporation ages and chemical composition of a migmatitic schist in the Obudu plateau: Evidence for Paleoproterozoic (ca. 1789 Ma) component in the basement complex of southeastern Nigeria. Journal of Mining and Geology, 33, 81-88.

Fan, \& Kerrich. (1997). Geochemical characteristics of aluminium depleted and undepleted komatiites and HREE-enriched low-Ti tholeiites, western Abitibi greenstone belt: A heterogeneous mantle plume convergent margin environment. Geochimica et Cosmochimica Acta, 61. 
Ferré, E. C, Gleizes, G., \& Caby, R. (2002). Obliquely convergent tectonics and granite emplacement in the Trans-Saharan belt of Eastern Nigeria: A synthesis. Precambrian Research, 114, 199-219.

Ferré, E., \& Caby, R. (2006). Granulite facies metamorphism and charnockite plutonism: Examples from the Neoproterozoic Belt of northern Nigeria. Jobname: PGA (Alden DTD), 2, 3.

Ferré, E., Caby, R., Peucat, J. J., Capdevila, R., \& Monié, P. (1998). Pan-African, post-collisional, ferro-potassic granite and quartz-monzonite plutons of Eastern Nigeria. Lithos, 45, 255-279.

Frost, B. R., Barnes, C. G., Collins, W. J., Arculus, R. J., Ellis, D. J., \& Frost, C. D. (2001). A geochemical classification for granitic rocks. Journal of Petrology, 42, 2033-2048.

Harris, N. B., Pearce, W. J. A., \& Tindle, A. G. (1986). Geochemical characteristics of collision-zone magmatism. Geol. Soc. Sp. Publ., 19, 67-81.

Hutton, D. H. W., Dempster, T. J., Brown, P. E., \& Becker, S. D. (1990). A new mechanism of emplacement: Intrusion in active extensional shear zones. Nature, 343, 452-455.

Isseini, I. (2011). Croissance et différenciation crustales au Néoprotérozö̈que: Exemple du domaine panafricain du Mayo-Kebbi au Sud-Ouest du Tchad (p. 339). Thèse de Doctorat UniversitéHenri Poincaré, Nancy, France.

Isseini, I., André-Mayer, A. S., Vanderhaeghe, O., Barbey, P., \& Deloule, E. (2012). A-type granites from the Pan-African orogenic belt in south-western Chad constrained using geochemistry, $\mathrm{Sr}-\mathrm{Nd}$ isotopes and U-Pb geochronology. Lithos, 153, 39-52.

Jenner, G. A., Longerich, H. P., Jackson, S. E., \& Fryer, B. J. (1990). ICP-MS - A powerful tool for high precision trace element analysis in earth sciences: Evidence from analysis of selected U.S.G.S. reference samples. Chemical Geology, 133-148.

Kankeu, B., Greiling, R. O., Nzenti, J. P., Bassahak, J., \& Hell, J. V. (2012). Strain partitioning along the neoproterozoic Central Africa Shear Zone system: Structures and magnetic fabrics (AMS) from the Meiganga area, Cameroun. N. Jb. Geol. Paläont, Abh., 265, 27-47. Stuttgart.

Kuno, H. (1968). Differectiation of basaltic magmas. In H. H. Hess, \& A. Poldevaart (Eds.), Basalts (Vol. 2, pp. 623-688). New York Interscience.

Kwekam, M. (1993). Le massif plutonique calco-alcalin Pan-Africain de Fomopéa (Ouest Cameroun) Cadre structural - Pétrologie - Géochime Interprétation géodynamique (p. 184).Thèse de Doctorat. Univ., Ydé.

Le Maitre, R. W., Bateman, P., Dubek, A., Keller, J., Lameyre, J., Le Bas, M. J., Sabine, P. A., Schmid, R., Sørensen, H., Streckeisen, A., Woolley, A. R., \& Zanettin, B. (1989). A classification of igneous rocks and glossary of terms (p. 193). Recommendations of the International Union of Geological Sciences Sub-commission on the Systematics of Igneous Rocks, Blackwell, Oxford.

Liégeois, J. P., Black, R., Navez, J., \& Latouche, L. (1994). Early and late Pan-African orogenies in the Air assembly of terranes (Tuareg shield Niger). Prec. Res., 67, 59-88.

Liégeois, J. P., Navez, J., Hertogen, J., \& Black, R. (1998). Contrasting origin of post-collisional high-K calc-alkaline and shosonitic versus alkaline and peralkaline granitoids. The use of sliding normalization. Lithos, 45, 1-28.

Louis, P. (1970). Contribution géophysique à la connaissance géologique du bassin du Lac Tchad (p. 308). Mémoires ORSTOM, Paris.

Maniar, P. D., \& Piccoli, P. M. (1989). Tectonic discrimination of granitoids. Geological Society of American Bulletin, 101, 635-643.

Middlemost, E. A. K. (1991). Towards a comprehensive classification of Igneous rocks and magmas. Earth Science Reviews., 31, 73-87. Elsevier Science Publishers, B. V, Amsterdam, Australia.

Ngako, V. (1986). Evolution métamorphique et structurale de la bordure Sud-ouest de la "série de Poli" (segment camerounais de la chaîne panafricaine) (p. 158). Mémoires et documents duCentre Armoricain d'étude structurale des socles, Rennes, $\mathrm{N}^{\circ} 5$.

Ngako, V., \& Njonfang, E. (2011). Plates amalgamation and plates destruction, the western Gondwama history (pp. 3-34). Closson, Damien (Eds.), Tectonics. Intech. UK.

Ngako, V., Affaton, P., \& Njonfang, E. (2008). Pan-African tectonics in northwestern Cameroon: Implication for the history of western Gondwana. Gondwana Research, 14, 509-522. 
Ngako, V., Jégouzo, P., \& Soba, D. (1990). Déformation et métamorphisme dans la chaîne Pan-Africaine de Poli (Nord-Cameroun). Implications géodynamiques et paléogéographiques. Journal of African Earth Sciences, 9(3/4), 541-555.

Nguiessi-Tchankam, C., \& Vialette, Y. (1994). Données géochronologiques (Rb-Sr, $\mathrm{Pb}-\mathrm{Pb}, \mathrm{U}-\mathrm{Pb}$ ) sur le complexe plutonique de Bandja (Centre-Ouest Cameroun). Comptes Rendus de l'Académie des Sciences Paris, 319(II), 317-324.

Njanko, T., Nedélec, A., \& Affaton, P. (2006). Synkinematic high-K calcalkaline plutons associated to the Pan-African central Cameroon shear zone (west-Tibati area): Petrology and geodynamic significance. $J$. Afr. Earth Sci., 44(4), 494-510.

Njel, U. O. (1988). Contribution à l'étude de l'orogénèse Panafricaine. La ceinture volcano-sédimentaire de Poli (Nord Cameroun): Lithostratigraphie, paléogéographie, pétrographie, géochimie, minéralisations cuprifères associées (p. 220). Thèse de Doctorat de l'INPL.

Njiekak, G., Dörr, W. J.-P., Tchouankoué, J.-P., \& Zulauf, G. (2008). U-Pb zircon and microfabric data of (meta) granitoids of western Cameroon: Constraints on the timing of pluton emplacement and deformation in the Pan-African belt of Central Africa. Lithos, 102, 460-477.

Nzenti, J. P., Ngako, V., Kambou, R., Penaye, J., Bassahak, J., \& Njel, U. O. (1992). Structures régionales de la chaîne Panafricaine du Nord Cameroun. Compte Rendu Académie des Sciences, Paris, t. 315(II), 209-215.

Nzolang, C., Kagani, H., Nzenti, J.-P., \& Holtz, F. (2003). Geochemistry andpreliminary Sr-Nd isotopic data on the Neoproterozoic granitoidsfrom Bantoum area, West, Cameroon: Evidence for a derivation fromPaleoproterozoic to Archean crust. Polar Geoscience, Tokyo, 16, 196-226.

Penaye, J., Kröner, A., Toteu, S. F., Van Schmus, W. R., \& Doumnang, J. C. (2006). Evolution of the Mayo Kebbi region as revealed by zircon dating: An early (ca. $740 \mathrm{Ma}$ ) Pan-African magmatic arc in southwestern Chad. Journal of Afr. Earth Sc., 44, 530-542.

Pinna, P., Calvez, J. V., Abessolo, A., Angel, J. M., Mekoulou-Mekoulou, T., Mananga, G., \& Vernhet, Y. (1994). Neoproterozoic events in the Tcholliré area: Panafrican crustal growth and geodynamic in Central Northern Cameroon (Adamaoua and North Provinces). Journal of African Earth Sciences, 18, 347-353.

Pouclet, A., Vidal, M., Doumnang, J. C., Vicat, J. P., \& Tchameni, R. (2006). Neoproterozoic crustal evolution in Southern Chad: Pan-African ocean basin closing, arc accretion and late- to post-orogenic granitic intrusion. Journal of Afr. Sc., 44, 543-560.

Provost et al. (1979). Process identification and search for optimal differentiation parameters from element data. General presentation with imphasis on the fractional crystallization process. Geoch. Cosm. Acta., 43, 497-501.

Rapp, R. P., \& Watson, E. B. (1995). Dehydratation melting of metabasalt at 8-32 kbar: Implications for continental growth and crust-mantle recycling. Journal of Petrology, 36, 891-931.

Roberts, M. P., \& Clemens, J. D. (1993). Origin of high-potassium, calcalkaline, I-type granitoids. Geology, 21, $825-828$.

Stephen, A. N. (2006). Structure of the earth and the origin of magmas. EENS, Tulane University.

Tagne-Kamga, G. (2003). Petrogenesis of the Neoproterozoic Ngondo Plutonic complex (Cameroon, west central Africa): A case of latecollisional ferro-potassic magmatism. Journal of African Earth Sciences, 36, 149-171.

Tchameni, R., Sun, F., Dawai, D., Tékoum, L., Noo Neguel, E., Vanderhaeghe, O., Nzolang C., \& Nguihdama, D. (2015). Zircon dating and mineralogy of the Mokong Pan-African magmatic epidote-bearing granite (North Cameroon). Journal of Earth Sci Geol Rundsch.

Toteu, S. F., Bertrand, J. M., Penaye, J., Macaudière, J., Angoua, S., \& Barbey, P. (1991). Cameroon, a tectonic keystone in the Pan African network.

Toteu, S. F., Macaudière, J., Bertrand, J. M., \& Dautel, D. (1990). Metamorphique zircon from North Cameroon: implications for the Pan-African evolution of Central Africa. Geologishe Rundschau, 79(3), 777-788.

Toteu, S. F., Michard, A., Bertrand, J. M., \& Rocci, G. (1987). U/Pb dating of Precambrian rocks from northern Cameroon, orogenic evolution and chronology of the Pan-African belt of Central Africa. Precambrian Research, 37, 71-97. 
Toteu, S. F., Penaye, J., \& Djomani, Y. (2004). Geodynamic evolution of the Pan-African belt in reference to Cameroon. Canadian Journal of Earth Sciences, 41, 73-85.

Toteu, S. F., Van Schmus, W. R., Penaye, J., \& Michard, A. (2001). New U-Pb and Sm-Nd data from north-central Cameroon and its bearing on the pre-Pan African history of central Africa. Precambrian Research, 108, 45-73.

Van Schmus, W. R., Oliveira, E. P., Da Silva Filha, A. F., Toteu, S. F., Penaye, J., \& Guimaraes, I. P. (2008). Proterozoic links between the Borborema Province, NE Brazil and Central African Fold Belt. Geological Society, London, Special Publications, 294, 69-99.

\section{Copyrights}

Copyright for this article is retained by the author(s), with first publication rights granted to the journal.

This is an open-access article distributed under the terms and conditions of the Creative Commons Attribution license (http://creativecommons.org/licenses/by/4.0/). 